\title{
НАУКОВА ПЛАТФОРМА ПРОФЕСІЙНОЇ ОСВІТИ: СТАЛИЙ РОЗВИТОК
}

\author{
Наукова доповід ь на XV Всеукраїнській науково-практичній конференції \\ «Науково-методичне забезпечення професійної освіти і навчання», \\ присвяченій 30-річчю Незалежності України та 15-річчю заснування \\ Iнституту профресійно-технічної освіти НАПН України (25 березня 2021 р.)
}

https://doi.org/10.37472/2707-305X-2021-3-1-17-1

До зо-річчя Незалежності Украйни та 15-річчя ІПТО НАПН Украйни

\section{НАУКОВА ПЛАТФОРМА ПРОФЕСІЙНОӦ ОСВІТИ: СТАЛИЙ РОЗВИТОК}

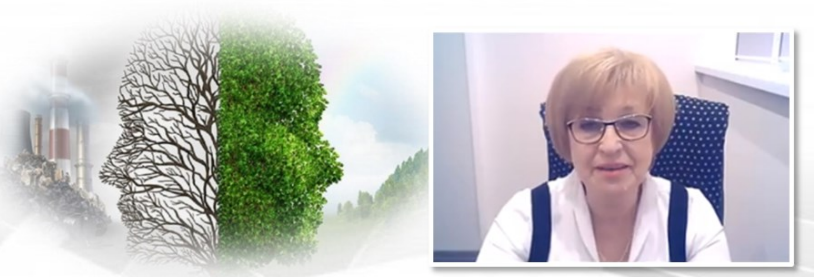

ВАЛЕНТИНА РАДКЕВИЧ -

доктор педагогічних наук, професор, дійсний член (академік) НАПн України, директор Інституту професійно-технічної освіти НАПН України

\section{РАДКЕВИЧ}

Валентина Олександрівна доктор педагогічних наук, профресор, дійсний член (академік) НАПН України, директор Iнституту профресійно-технічної освіти Начіональної академії педагогічних наук України, м. Київ, Україна

Анотація. У доповіді представлено інформаційно-аналітичний огляд основних напрямів і результатів діяльності Інституту професійно-технічної освіти НАПН України задля забезпечення науково-методичного супроводу модернізації професійної освіти, проведення експериментальної діяльності різних рівнів і впровадження інновацій. Наголошується, що в контексті забезпечення сталого розвитку національної освіти в умовах постійних трансформаційних змін Інститут профресійно-технічної освіти НАПН України вже n'ятнадиять років слугує потужною науковою платформою інноваційного становлення закладів професійної (професійно-технічної) і фахової передвищої освіти. Комунікаційною основою створеної наукової платформи визначено: плідну співпрацю з закладами профресійної, фрахової передвищої освіти та навчально-методичними (науково-методичними) центрами (кабінетами) профресійно-технічної освіти; співробітниитво з різними групами стейкхолдерів; комунікацію з органами державної та місцевої влади, міністерствами й відомствами; розвиток міжнародних наукових зв'язків. Особливу увагу зосереджено на висвітленні узагальнених і систематизованих результатів фундаментальних і прикладних наукових досліджень, що виконуються в Інституті професійно-технічної освіти НАПн України. Сформульовано рекомендації щодо модернізації вітчизняної професійної (професійно-технічної) та фахової передвищої освіти.

Ключові слова: професійна освіта; професійно-технічна освіта; фахова передвища освіта; Iнститут професійно-технічної освіти НАПН України; навчально-методичний (науково-методичний) иентр (кабінет) професійно-технічної освіти; науково-методичний супровід; модернізація професійної освіти.

Тридцять років Україна виборює власну державу, формує монолітну політичну націю, модернізує систему освіти. Для встановлення балансу між задоволенням сучасних потреб та інтересами майбутніх поколінь в основу української освітньої політики покладено Цілі Сталого Розвитку. В Україні глобалізаційні виклики поєдналися з кардинальними змінами, пов'язаними з реформуванням усіх сфер життя держави - іï суспільних та економічних відносин, системи освіти й науки. Саме тому й сучасна професійна та фахова передвища освіта перебувають у стані глибоких змін, що характеризуються:

- реформуванням системи управління закладами освіти;

- створенням їх нової архітектури та системи взаємодії;

- диверсифікацією джерел фінансування; 
- зростанням ролі автономії закладів освіти, запитами на розроблення та впровадження нових форм і методів організації освітнього процесу (зокрема, елементів дуальної, дистанційної освіти);

- зміною форм взаємодії між стейкхолдерами в рамках державно-приватного партнерства;

- зростаючими вимогами до змісту та якості освіти;

- актуалізацією ролі науково-експериментальної, аналітичної дорадчої діяльності представників освітньої спільноти.

За таких умов заклади освіти потребують серйозної підтримки не лише з боку влади та різних стейкхолдерів, але й наукових установ, покликаних забезпечити якісний науковометодичний супровід процесу модернізації сучасної професійної та фахової передвищої освіти. Наукові інституції повинні бути надійною науковою платформою всіх зазначених вище модернізаційних змін. Інститут професійнотехнічної освіти Національної академії педагогічних наук України $€$ такою платформою для вітчизняних закладів професійної (професійнотехнічної) освіти (далі - ЗП(ПТ)О) вже 15 років. Це - єдина в Україні наукова установа, що здійснює науково-методичний супровід закладів професійної (професійно-технічної) та фахової передвищої освіти.

Всі ці роки Інститут керувався інтересами вітчизняної професійної (професійно-технічної), а з 2016 року - й фахової передвищої освіти. Комунікаційною основою збудованої нами наукової платформи є:

- плідна практична співпраця з закладами професійної (професійно-технічної) та фахової передвищої освіти; науково-методичні контакти 3 навчально-методичними (науково-методичними) центрами (кабінетами) професійно-технічної освіти;

- співробітництво з різними групами стейкхолдерів, зацікавлених у модернізації вітчизняної системи професійної освіти;

- комунікація з органами державної та місцевої влади, міністерствами, департаментами, відомствами;

- розвиток міжнародних наукових зв'язків.

Тісні контакти з широкими партнерськими колами дають змогу:

- популяризувати наукові досягнення;

- поширювати передовий науково-педагогічний досвід;
- здійснювати наукове керівництво інноваційною освітньою діяльністю ЗП(ПТ)О;

- готувати педагогічні, науково-педагогічні кадри для системи професійної (професійнотехнічної), фахової передвищої та вищої освіти;

- підвищувати кваліфікацію наукових, науковопедагогічних працівників;

- здійснювати інформаційно-аналітичну, експертну, консультативну дорадчу діяльність тобто реально впливати на освітню політику держави та практичну діяльність освітніх закладів.

У ході виконання наукових досліджень підготовлено: 1724 види наукової; 128 - виробничопрактичної; 77 - навчальної; 38 - довідкової продукції. До Електронної бібліотеки НАПН України вченими Інституту завантажено понад 2 тис. ресурсів і зафіксовано понад 200 тис. їх завантажень. Інтерес до наукових напрацювань Інституту визначається системою рейтингів. Зокрема, у Google Scholar індекс Гірша Інституту зріс до 48, а «10-індекс» - до 290.

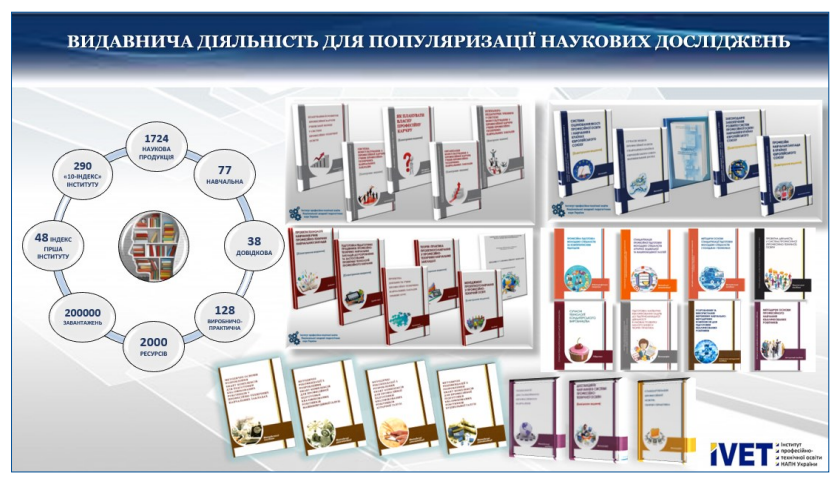

Видана Інститутом наукова продукція має важливе значення для модернізації професійної (професійно-технічної) та фахової передвищої освіти, зокрема для: підвищення якості освіти, оптимізації механізмів управління освітніми закладами, сприяння розвитку малого бізнесу через формування підприємницької та кар'єрної компетентностей, інтернаціоналізації професійної освіти через вивчення й поширення зарубіжного досвіду, впровадження проєктного навчання, вдосконалення підготовки педагогічних кадрів, формування в суб'єктів освітнього процесу цифрових навичок і цифрової культури, розвитку дистанційної і дуальної форми здобуття освіти тощо.

Інститутом видається три наукових періодичних видання, два з яких увійшли до міжнародних наукометричних баз. Журнал «Професійна педагогіка» - наукометричне фахове видання, включене до категорії «Б». 32019 р. виходить 


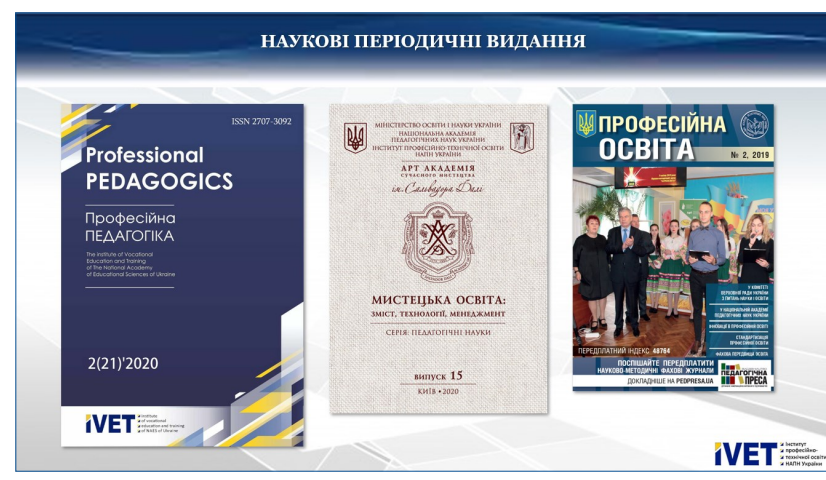

англійською та українською мовами, має високий рейтинг за результатами моніторингу міжнародної бази Index Copernicus International (85.01) i входить до ТОП-5 наукових періодичних видань НАПН України (2020р.).

Інститут $€$ також співзасновником наукометричного збірника наукових праць, орієнтованого на фахівців у галузі дизайну, «Мистецька освіта: зміст технології, менеджмент», що високо індексується в наукометричній базі даних Index Copernicus International.

Знаним і популярним у наукових та освітянських колах $є$ науково-методичний журнал «Професійна освіта», в якому друкуються матеріали з питань дидактики та історії професійної школи, виховання, професійної орієнтації та ефективного навчання у ЗП(ПТ)О, коментарі і статті провідних профтехосвітян України. Над випусками журналу в усі роки його функціонування працювала фахова команда наукових співробітників Інституту, здійснюючи редагування й рецензування численних матеріалів.

За 15 років вченими Інституту розроблено майже 200 інновацій - більше 20 концепцій і моделей, понад 40 методик і технологій та десятки інших наукових розробок для системи П(ПТ)О для більш ніж 15 напрямів модернізації професійної (професійно-технічної) та фахової передвищої освіти.

У модернізації професійної (професійнотехнічної) та фахової передвищої освіти велике науково-теоретичне значення мали концепції:

- розвитку професійного навчання незайнятого населення на виробництві;

- професійної орієнтації молоді на робітничі професії;

- модульного професійного навчання кваліфікованих робітників на виробництві;

- формування професійної мобільності кваліфікованих робітників;

- формування в учнів ціннісного ставлення до здоров'я;

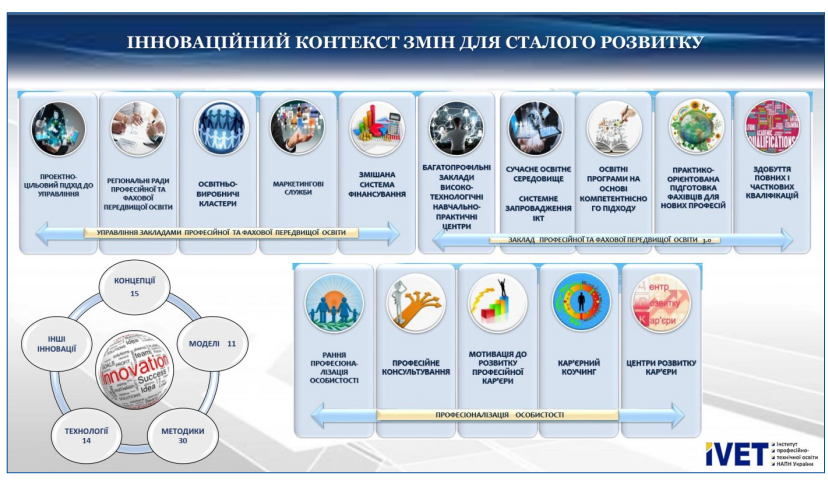

- уявлень про професійний успіх;

- розвитку інформаційно-аналітичної компетентності педагогічних працівників;

- проєктування інформаційно-освітнього середовища ЗП(ПТ)О;

- проєктного і дистанційного професійного навчання;

- проєктування SMART-комплексів для закладів професійної освіти;

- управління розвитком професійної освіти в умовах ринкової економіки;

- діяльності центрів професійної кар'єри;

- стандартизації професійної освіти фахових молодших бакалаврів;

- оцінювання якості підготовки фахівців у закладах фахової передвищої освіти.

Науково-практичне значення мали також розроблені нами моделі:

- управління маркетингом системи П(ПТ)О;

- забезпечення організаційно-педагогічних умов розвитку інформаційно-аналітичної компетентності керівників 3П(ПТ)О;

- модульного навчання кваліфікованих робітників на виробництві;

- мережевої взаємодії соціальних партнерів, закладів П(ПТ)О та профільних класів середніх шкіл у підготовці конкурентоздатних фахівців;

- інформаційно-освітнього

середовища закладу освіти;

- ресурсного центру підготовки фахівців різних рівнів кваліфікацій;

- методичної системи формування готовності педагогічних працівників до стандартизації професійної освіти;

- дистанційного професійного навчання;

- системи кар'єрного консультування учнів;

- онлайн-консультування учнів 3 розвитку професійної кар'єри.

У кількох сотнях закладів освіти впроваджено розроблені нами методики, зокрема підготовки викладачів до: 
- запровадження особистісно-розвивальних педагогічних технологій;

- застосування дистанційного навчання;

- стандартизації професійної підготовки майбутніх фахових молодших бакалаврів;

- створення системи консультування з професійної кар'єри;

- формування змісту освіти на компетентнісній основі;

- вибору й розроблення проєктних технологій, організації проєктної діяльності у закладах П(ПТ)О, контролю й оцінювання ії̈ результатів;

- розвитку професійної, енергозбережувальної, екологічної, інформаційно-аналітичної, самоосвітньої, проєктної, цифрової, кар'єрної та підприємницької компетентностей педагогічних працівників, майстрів виробничого навчання та учнів;

- розроблення професійних і освітніх стандартів;

- проєктування дистанційних курсів;

- розроблення електронних підручників;

- вимірювання освітніх результатів;

- організації дистанційної та дуальної форми навчання;

- моніторингу та контролю успішності дистанційного навчання майбутніх кваліфікованих робітників;

- управління конкурентоспроможністю закладу освіти;

- розвитку культури безпеки професійної діяльності персоналу підприємств.

Модернізації професійної (професійнотехнічної) освіти значно сприяли підготовлені науковцями Інституту та експериментально перевірені в закладах освіти технології:

- проєктування дистанційних курсів для закладів професійної освіти, інформаційноосвітнього середовища та змісту компетентнісно орієнтованого навчання;

- розвитку кар'єрних орієнтацій учнів, їх ділової активності та фінансової грамотності, кар'єрної і підприємницької компетентностей, мотивації до розвитку професійної кар'єри, соціального партнерства у ЗП(ПТ)О в умовах дуальної форми навчання;

- формування уявлень учнів про професійну кар'єру, тестового контролю успішності навчання фахових молодших бакалаврів;

- маркетингово-моніторингового управління закладом З(ПТ)О як проєктноорієнтованою організацією.

Вчені Інституту системно опікуються інноваційною освітньою діяльністю ЗП(ПТ)О, здійснюючи

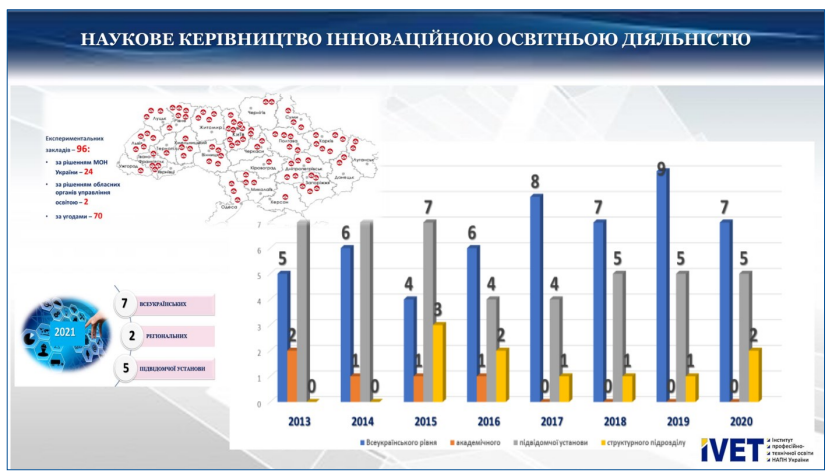

наукове керівництво експериментами всеукраїнського та регіонального рівнів.

Педагоги майже 100 закладів освіти з усіх областей України залучені до науковоекспериментальної діяльності різних рівнів, створюючи під керівництвом досвідчених учених власні інновації, здійснюючи їх експериментальну перевірку, популяризуючи через наші конференції, семінари, вебінари, наукові й науковометодичні видання результати виконаної інноваційної діяльності. Для вчених Інституту ця співпраця була й залишається майданчиком апробації власних наукових концепцій, упровадження наукових розробок, визрівання нових наукових ідей.

Під керівництвом наукових співробітників Інституту було завершено 11 експериментів всеукраїнського рівня, що дали змогу розробити й експериментально перевірити особливості:

- управління закладом освіти в умовах ринкової економіки;

- розвитку освітнього маркетингу;

- дуальної освіти;

- створення інформаційно-освітнього середовища, електронних навчальних ресурсів, центру професійної кар'єри;

- технологій проєктного навчання;

- формування професійної, енергоефективної, кар'єрної, проєктної компетентності майбутніх фахівців тощо.

Нині діє 7 експериментів всеукраїнського рівня, у ході яких:

- розроблено дистанційні механізми організації професійного навчання учнівської молоді і дорослих, які проживають на тимчасово окупованих територіях;

- експериментально доведено широкі можливості використання технологій дистанційного навчання для вдосконалення професійної підготовки майбутніх квітникарів, декораторів, флористів;

- здійснюється апробація науково-методичного забезпечення професійної підготовки кваліфіко- 
ваних робітників для сфери обслуговування відновлювальних систем сонячної і теплової енергетики;

- розробляються механізми розвитку приватно-публічного партнерства у сфері П(ПТ)О з використанням стратегічного менеджменту;

- перевіряються педагогічні умови формування готовності майбутніх кваліфікованих робітників до підприємницької діяльності;

- упроваджується методика професійної підготовки майбутніх кваліфікованих робітників за дуальною формою здобуття освіти.

Усі роки свого існування Інститут розвивав і зміцнював свої міжнародні зв'язки. Налагоджено активну співпрацю з багатьма міжнародними організаціями, освітніми закладами та науковими установами:

- Німецьким товариством технічного співробітництва (GTZ);

- Федеральним Інститутом професійної освіти Німеччини (Bundesinstitutfür Berufsbildung - BIBB);

- Інститутом техніки та освіти в Технічному Університеті м. Бремен (ITB, Федеративна республіка Німеччина);

- Європейським фондом освіти (ЄФО);

- Університетом м. Констанц (Німеччина);

- Університетом м. Валенсія (Іспанія);

- Віденським університетом економіки та бізнесу (Австрія);

- Інститутом підвищення кваліфікації «Міжнародна професійна академія «ТуранПрофі» (Республіка Казахстан);

- Республіканським інститутом професійної освіти (Республіка Білорусь);

- Вищою школою лінгвістичною у Ченстохові (Республіка Польща);

- Академією імені Яна Длугоша у Ченстохові (Республіка Польща).

Міжнародна наукова діяльність постійно зміцнюється завдяки активній участі вчених Інституту у міжнародних проєктах, серед яких варто відзначити:

- проєкт «Ефективне управління трудовою міграцією та її кваліфікаційними аспектами» у межах співпраці з Субрегіональним Бюро МОП для країн Східної Європи і Центральної Азії (2013 р.);

- проєкт ЄC TWINING «Модернізація законодавчих стандартів та принципів освіти і навчання відповідно до політики Європейського Союзу щодо навчання впродовж життя» (2012-2014 рр.);
- проєкт ЄС програма ТЕМПУС «ЕкоБРУ» (20132016 pp.);

- проєкт програми ЄC Erasmus+ 3 міжнародного обміну студенської молоді «Joker - my business, my identity» (Joker - moja firma, moje ja)» (2015 p.);

- проєкт з Федеральним Інститутом професійної освіти Німеччини (Bundes Institut für Berufsbildung - BIBB) (2013-2015 pp.);

- проєкт Світового Банку «Розвиток трудового потенціалу в Україні» (2013-2014рр.);

- проєкт «Професійна спрямованість вивчення іноземних мов у професійно-технічних навчальних закладах» (2015 р.);

- проєкт програми ЄC Erasmus+ у сфері вищої освіти «Удосконалення практико-орієнтованої підготовки викладачів професійної освіти і навчання»;

- нині діючий проєкт Erasmus+ «Нові механізми управління на основі партнерства та стандартизації підготовки викладачів професійної освіти в Україні».

У ході міжнародної проєктної діяльності вченими Інституту:

- розроблено та впроваджено дистанційні курси для викладачів 3П(ПТ)О («Культура екологічної безпеки професійної діяльності у будівельній галузі», «Енергоефективна компетентність педагогічних працівників ПТНЗ будівельного профілю», «Еко-орієнтовані педагогічні технології»);

- видано «Дайджест курсів підвищення екологічної компетентності викладачів, учнів та студентів» та «Еко-орієнтовані технології професійного навчання. Збірник екологічних проєктів»;

- підготовлено аналітичні довідки за результатами порівняльного аналізу навчальних планів підготовки викладачів економіки для системи професійної освіти у закладах вищої освіти України та зарубіжжя;

- обґрунтовано модель практико-орієнтованої підготовки викладачів професійної освіти і навчання та розроблено методичні рекомендації щодо її вдосконалення;

- проведено загальнонаціональне опитування щодо сучасного стану управління підготовкою педагогів професійного навчання;

- розроблено дорожню карту змін управління професійною підготовкою викладачів для сучасної системи П(ПТ)О України тощо.

Значні результати наукового колективу Інституту зумовили зростання їх інформаційноаналітичної, консультативної, експертної та 


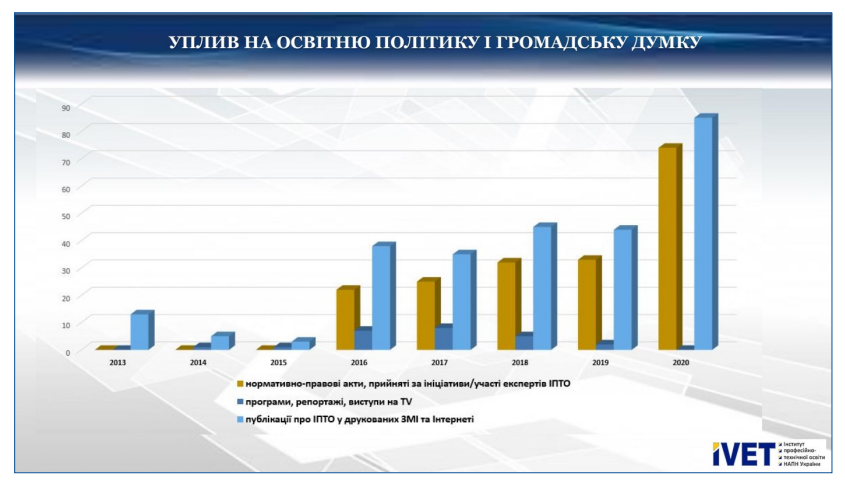

дорадчої діяльності, що реалізовувалася через співпрацю з комітетами Верховної Ради України, виконання програми співпраці з МОН України, іншими міністерствами й відомствами, обласними департаментами освіти, громадськими організаціями та об'єднаннями.

В Інституті функціонує 5 наукових шкіл, покликаних формувати нове покоління дослідників, зокрема із середовища педагогів-практиків системи професійної (професійно-технічної) та фахової передвищої освіти:

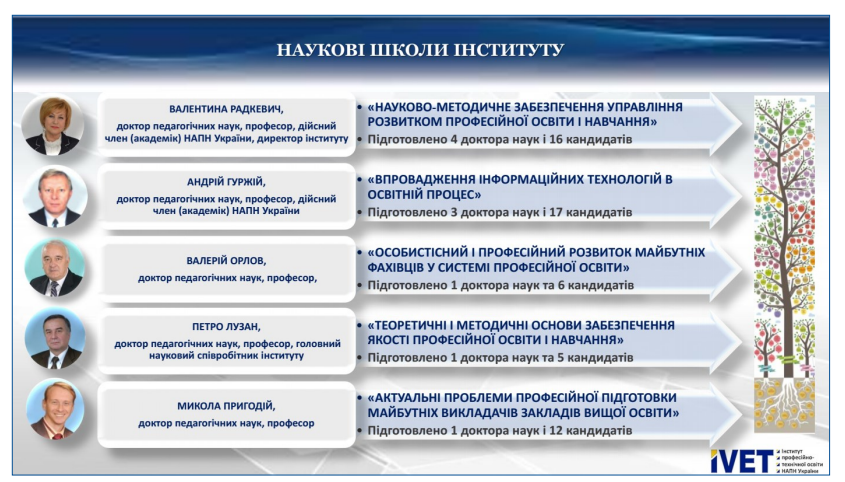

- «Науково-методичне забезпечення управління розвитком професійної освіти і навчання» (керівник - B.О. Радкевич, доктор педагогічних наук, професор, дійсний член (академік) НАПН України, директор Інституту), підготовлено 18 кандидатів та 5 докторів наук;

- «Впровадження інформаційних технологій у освітній процес» (керівник - А.М. Гуржій, доктор технічних наук, професор, дійсний член (академік) НАПН України), підготовлено 17 кандидатів та 3 доктори наук;

- «Особистісний і професійний розвиток майбутніх фахівців у системі професійної освіти» (керівник - В.Ф. Орлов, доктор педагогічних наук, професор, головний науковий співробітник Інституту), підготовлено 6 кандидатів та 1 доктора наук;

- «Теоретичні і методичні основи забезпечення якості професійної освіти і навчання» (керівник - П.Г. Лузан, доктор педагогічних наук, професор, головний науковий співробітник (нституту), підготовлено 5 кандидатів та 1 доктора наук;

- «Актуальні проблеми професійної підготовки майбутніх викладачів закладів вищої освіти» (керівник - М.А. Пригодій, доктор педагогічних наук, професор), підготовлено 12 кандидатів та 1 доктора наук.

Зважаючи на високий рівень підготовки кадрового складу Інституту упродовж усіх років, ми здійснювали не лише наукову, але й освітню діяльність, зокрема - підготовку й атестацію наукових і науково-педагогічних кадрів в аспірантурі й докторантурі, а з 2018 року - у магістратурі. За цей час було підготовлено 48 магістрів, 55 кандидатів і 13 докторів наук, видано 580 сертифікатів, що засвідчували підвищення кваліфікації, наукових, науково-педагогічних, педагогічних працівників.

Цілеспрямована робота Інституту з підготовки кадрів вищої кваліфікації знайшла своє продовження в діяльності Ради молодих вчених, очолюваної доктором педагогічних наук О.П. Радкеви чем. Рада опікується вдосконаленням освітньої програми підготовки докторів філософії, вводить нові форми роботи для забезпечення програмних результатів, удосконалює механізми доступу здобувачів освіти до інформації про дотримання академічної доброчесності та вибору індивідуальної освітньої траєкторії, забезпечує відкритий доступ до інформації про шляхи вирішення дискусійних і конфліктних питань, працює над підвищенням наукометричної активності та наукового іміджу молодих дослідників.

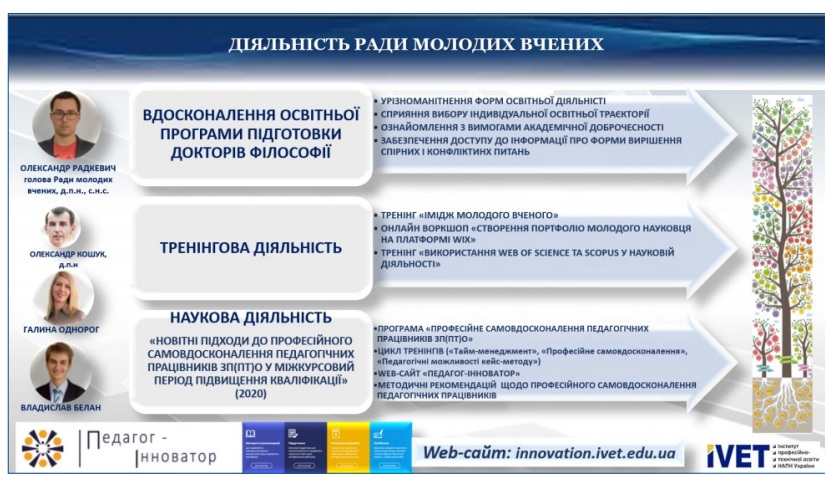

Важливим етапом у діяльності Ради молодих вчених стало наукове дослідження «Новітні підходи до професійного самовдосконалення педагогічних працівників ЗП(ПТ)О у міжкурсовий період підвищення кваліфікації» (2020р.), у ході якого підготовлено програму та методичні рекомендації з професійного самовдосконалення педагогів, проведено курс тренінгів, розроблено 
вебсайт «Педагог-інноватор», що став сучасною комунікаційною платформою для популяризації освітніх інновацій, обміну педагогічним досвідом, розвитку самоосвітньої компетентності педагогічних працівників.

Таким чином, за 15 років вченими Інституту професійно-технічної освіти НАПН України виконано 25 наукових досліджень, проведено понад 20 експериментів всеукраїнського та регіонального рівнів, здійснено 10 міжнародних проєктів, результати яких сприяли реалізації багатьох Цілей Сталого Розвитку, а саме:

- забезпечення здорового способу життя, сприяння благополуччю та якісній освіті (Ціль 3. Міцне здоров'я та благополуччя) через діяльність Центру здорового способу життя та профілактики ВІЛ/СНІД, метою якого $€$ упровадження спецкурсу зі здорового способу життя, проведення круглих столів, лекцій, психологічних тренінгів, благодійних волонтерських акцій для учнів, квестів;

- формування й розвиток енергозбережувальної та екологічної компетентностей учнів, студентів, педагогів, працівників підприємств для сприяння доступу всіх людей до надійних, сталих і сучасних джерел енергії (Ціль 7. Доступна ma чиста енергія);

- забезпечення переходу суспільства до раціональних моделей споживання й виробництва шляхом сприяння професійній підготовці кваліфікованих робітників для сфери обслуговування відновлювальних систем сонячної і теплової енергетики (Ціль 12. Відповідальне споживання та виробництво) через діяльність Центру енергоефективності, проведення його працівниками експериментальної діяльності всеукраїнського рівня, впровадження навчального курсу «Основи енергоефективності», дистанційних курсів підвищення кваліфікації вчителів, всеукраїнських науково-практичних вебінарів з удосконалення екологічної компетентності педагогічних працівників (2020 р.);

- сприяння безперервному, всеохопному і сталому економічному зростанню, повній і продуктивній зайнятості та гідній праці для всіх шляхом стимулювання інновацій у галузі професійної кар'єри та підприємництва, формування й розвиток підприємницької і кар'єрної компетентності майбутніх фахівців (Ціль 8. Гідна праця та економічне зростання) через діяльність Центру сучасних професій і технологій навчання, що об'єднав для реалізації таких цілей зусилля

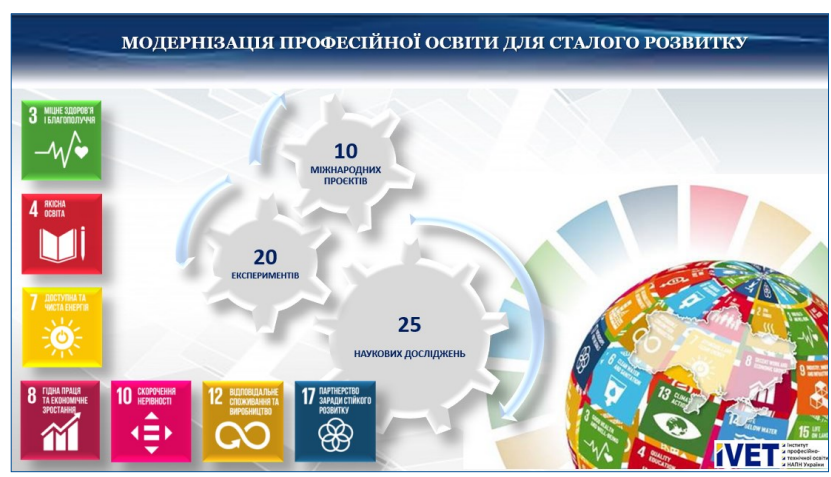

науковців різних лабораторій Інституту. Це дало змогу розробити професійні стандарти з професій «Методист ЗП(ПТ)О», «Майстер виробничого навчання», «Педагог професійного навчання»; підготувати й апробувати навчальну програму «Основи інноваційного підприємництва», узагальнити результати всеукраїнських експериментів 3 формування кар'єрної та підприємницької компетентностей і впровадження в ЗП(ПТ)О різних технологій підготовки молоді до професійної діяльності;

- сприяння мобільності людей для здобуття професійної освіти (Ціль 10. Скорочення нерівносmi) через злагоджену діяльність науковоорганізаційного відділу, лабораторій дистанційного професійного навчання та електронних навчальних ресурсів. Об'єднання потужностей зазначених структурних підрозділів дало змогу вивести на якісно новий рівень проведення експериментальної роботи всіх рівнів, удосконалити онлайн-комунікацію Інституту з ЗП(ПТ)О та іншими партнерами, створити й апробувати методики й технології розвитку цифрової грамотності, компетентності та культури суб'єктів освітнього процесу в системі професійної (професійно-технічної) освіти;

- сприяння мобільності, відкритості, конкурентності професійної освіти для розбудови миролюбного і всеохопного суспільства задля сталого розвитку (Ціль 17. Партнерство заради сталого розвитку) через активну діяльність лабораторії зарубіжних систем з посилення міжнародних наукових зв'язків, вивчення й імплементації кращих світових практик у вітчизняну систему професійної (професійно-технічної) та фахової передвищої освіти, участь у проєктній діяльності, активізацію експертної, консультативної та дорадчої діяльності співробітників лабораторії. Результати наукових досліджень лабораторії становлять компаративне наукове підґрунтя для формування теоретичної бази практично всіх фундаментальних і прикладних наукових досліджень Інституту; 
- на забезпечення всеохоплюючої і справедливої якісної освіти та заохочення можливості навчання впродовж життя (Ціль 4. Якісна освіта) спрямовано діяльність усіх наукових досліджень Інституту. Крім того, вченими лабораторії науковометодичного супроводу підготовки фахівців у коледжах і технікумах обґрунтовано методичні основи стандартизації професійної підготовки майбутніх фахівців, оцінювання якості їх освіти, розроблення професійних та освітніх стандартів.

Попри пандемію, дистанційну форму роботи, складні соціально-економічні обставини, що склалися нині в нашій країні, дякуючи працездатності колективу установи, а також професіоналізму, компетентності, мобільності та самовідданості вчених, Інституту вдалося зробити вагомий внесок у модернізацію національної системи професійної (професійно-технічної) та фахової передвищої освіти, що підтверджується численними нагородами й відзнаками. Наші вчені отримали 18 медалей, 23 дипломи у конкурсі «Національне визнання наукових досягнень» Міжнародної спеціалізованої виставки «/нноватика в сучасній освіті» та звання «Лідер сучасної освіти».

Своїм науковим успіхам колектив завдячує також злагодженій роботі структурних підрозділів Інституту - науково-організаційному та експлуатаційно-технічному відділам, бібліотеці, бухгалтерії, відділу кадрів, канцелярії, профспілковому комітету, працівники яких організовували онлайнкомунікацію наукових співробітників, лабораторій, установи в цілому, забезпечували комфортні й безпечні умови праці та відчуття стабільності.

Узагальнюючи 15 років діяльності Інституту, колектив якого ніколи не перевищував 100 осіб, маю подякувати всім його працівникам і науковим співробітникам за готовність до активної участі у реформуванні й розвитку вітчизняної професійної та фахової передвищої освіти. Ніколи соціально-економічні чи пандемічні проблеми не обмежували нашу діяльність, оскільки ґрунтувалася вона на засадах наукової організації праці та відданості членів колективу. Щира подяка Національній академії педагогічних наук України, особисто президенту В.Г. Кременю, Відділенню професійної освіти і освіти дорослих НАПН України та академіку-секретарю Відділення Н.Г.Ничкало за підтримку наших інноваційних наукових пошуків. Окрема подяка нашим партнерам - за готовність до співпраці, обміну думками, ідеями й досвідом.
Всі ми згуртовані єдиною метою - сприяти сталому розвитку нашої країни, суспільства й системи освіти. Ця єдність - є запорукою наших майбутніх успіхів, у що ми всі щиро віримо.

\section{СПИСОК ВИКОРИСТАНИХ ДЖЕРЕЛ}

Алєксєєва, С.В., Єршова Л.М., Закатнов, Д.О., Величко, Н.О., Кузьмінська, Л.Д., Лозовецька, В.Т., \& Орлов, В.Ф. (2019). Система консультування 3 професійної кар'єри учнів професійно-технічних навчальних закладів : монографія (Д.О. Закатнов, ред.). Житомир: «Полісся». https:// lib.iitta.gov.ua/717388/

Алєксєєва, С.В., Базиль, Л.О., Гриценок, І.А., Єршова, Л.М., Закатнов, Д.О., Орлов, В.Ф. \& Сохацька, Г.В. (2020). Підготовка майбутніх кваліфікованих кадрів до підприємницької діяльності в умовах розвитку малого бізнесу: теорія і практика : монографія. Житомир: «Полісся». https://cutt.ly/ LcDY7hx

Алєксєєва, С.В., Гриценок, І.А., Закатнов, Д.О., Кузьмінська, Л.Д. \& Орлов, В.Ф. (2019). Психологопедагогічні тренінги у системі консультування $з$ професійної кар'єри учнів професійно-технічних навчальних закладів : навчальний посібник (Д.О. Закатнов, ред.). Житомир: «Полісся». https:// lib.iitta.gov.ua/717525/

Алєксєєва, С.В., Єршова, Л.М., Закатнов, Д.О., Лозовецька, В.Т., \& Орлов, В.Ф. (2018). Планування й розвиток професійної кар'єри учнівської молоді у системі професійно-технічної освіти : навчальний посібник (Д.О. Закатнов, ред.). Житомир: «Полісся». https://lib.iitta.gov.ua/712226/

Аніщенко, В.М., Артюшина, М.В., Герлянд, Т.М., Кулалаєва, Н.В., Шимановський, М.М., та ін. (2018). Проектна діяльність учнів професійно-технічних навчальних закладів: тренінг-курс : навчальний посібник (Н.В. Кулалаєва, ред.). Житомир: «Полісся». https://lib.iitta.gov.ua/712110/

Аніщенко, В.М., Артюшина, М.В., Герлянд, Т.М., Кулалаєва, Н.В., Романова, Г.М., Шимановський, М.М., \& Смирнова, І.М. (2019). Теорія і практика проектного навчання у професійно-технічних навчальних закладах : монографія (Н.В. Кулалаєва, ред.). Житомир: «Полісся». https://lib.iitta.gov.ua/718498/

Аніщенко, В.М., Кулалаєва, Н.В., Романова, Г.М., Пащенко, Т.М., Шимановський, М.М., та ін. (2019). Підготовка педагогічних прачівників професійнотехнічних навчальних закладів до розроблення та застосування проектних технологій професійного навчання: тренінг-курс : навчально-методичний посібник (Г.М. Романова, ред.). Житомир: «Полісся». https://lib.iitta.gov.ua/720949/

Базелюк, О.В. Спірін, О.М. Петренко, Л.М. Каленський А.А., \& Майборода Л.А. (2018). Технології дистанційного професійного навчання : методичний посібник. Житомир: «Полісся». https:// lib.iitta.gov.ua/713159/

Бородієнко, О.В., Радкевич, О.П., Базелюк, Н.В. \& Шимановський, М.М. (2018). Законодавче забезпечення розвитку систем професійної освіти $i$ навчання в країнах Європейського Союзу 
практичний посібник (О.В. Бородієнко, ред.). Київ: ІПТО НАПН України.

Гайдук, О.В., Герлянд, Т.М., Дрозіч, І.А., Кулалаєва, Н.В., \& Романова Г.М. (2020). Сучасні технології кондитерського виробництва : підручник. Житомир: «Полісся». https://cutt.ly/tcDOxZK

Інститут професійно-технічної освіти НАПН України. (n.d.). Головна. https://ivet.edu.ua/

Інститут професійно-технічної освіти НАПН України. (2021, 15-26 березня). XV Всеукраїнська науковопрактична конференція "Науково-методичне забезпечення професійної освіти і навчання». https://ivet.edu.ua/events/khv-vseukrayinskanaukovo-praktychna-konferentsiya

Каленський, А.А., Лузан, П.Г., Ваніна, Н.М., Пащенко, Т.М., Кравець, С.Г., \& Пятничук, Т.В. (2018). Стандартизація профресійної освіти: теорія і практика: монографія (А.А. Каленський, ред.). Житомир: «Полісся». https://lib.iitta.gov.ua/712845/

Кравець, С.Г. (2018). Розвиток проектної культури педагогів професійного навчання: основні вектори дослідження в контексті управління якістю освіти. In Л.Л. Сушенцева, Л.М. Петренко (ред.), Управління якістю освіти: досвід та інновації : колективна монографія (с. 86-109). Павлоград: ІМА-прес.

Кравець, С.Г. (2019). Формування ключових компетентностей майбутніх фахівців ресторанного сервісу у вищих професійних училищах. In Г.В. Єльникова (ред.), Адаптивне управління в освіті: професійні та громадсько активні школи (с. 5-50). Харків: Мачулин.

Організація Об'єднаних Націй. (2015). Цілі Сталого Розвитку. UNDP Україна. https://www.ua.undp.org/ content/ukraine/uk/home/sustainable-developmentgoals.html
Радкевич, В.О., Пуховська, Л.П., Бородієнко, О.В., Радкевич, О.П., Базелюк, Н.В., Корчинська, Н.М., Леу, С.О., \& Артемчук, В.В. (2018). Сучасні моделі професійної освіти і навчання в країнах Європейського Союзу: порівняльний досвід : монографія (В.О. Радкевич). Київ: ІПТО НАПН України. https:// lib.iitta.gov.ua/711545/

Радкевич, В.О., Пуховська, Л.П., Бородієнко, О.В., Радкевич, О.П., Базелюк, Н.В., Корчинська, Н.М. \& Леу, С.О. (2018). Системи оцінювання якості профресійної освіти і навчання в країнах Європейського Союзу : монографія (В.О. Радкевич, О.В. Бородієнко, ред.). Житомир: «Полісся». https://lib.iitta.gov.ua/721252/

Радкевич, О.П. (2020). Теорія і практика розвитку правової культури педагогічних прачівників закладів професійної освіти : монографія. Київ: Майстер Книг. http://lib.iitta.gov.ua/722096/

Свистун, В.І. \& Смирнова, І.М. (2018). Менеджмент проектного навчання у професійно-технічній освіті : практичний посібник. Київ: ІПТО НАПН України.

Kravets, S. (2020). Key competencies as the factors in personal and professional development of prospective skilled workers. In M. Duczmal, T. Nestorenko (Eds.), Organizational problems of life quality management in the conditions of globalization (pp. 70-76). Opole: The Academy of Management and Administration in Opole. https://www.wszia.opole.pl/wpcontent/uploads/2020/05/2_2021.pdf

Radkevych, V., Romanova, G., Artiushyna, M., \& Borodiyenko, O. (2018). Vocational education and training and vocational teacher education system in Ukraine. In Th. Deissinger, V. Braun (Eds.), Improving Teacher Education for Applied Learning in the Field of VET (pp. 127-156). Münster - New York: Waxmann.

\section{A SCIENTIFIC PLATFORM OF PROFESSIONAL EDUCATION: SUSTAINABLE DEVELOPMENT}

Scientific report at the 15th All-Ukrainian Scientific and Practical Conference "Scientific and Methodological Support for Vocational Education and Training", devoted to the 30th anniversary of Ukraine's Independence and 15th anniversary of the Institute of Vocational Education and Training of NAES of Ukraine founding $($ March 25, 2021)

\section{Valentyna Radkevych}

DSc in Pedagogy, Professor, Full Member (Academician) of NAES of Ukraine, Director, Institute of Vocational Education and Training of the National Academy of Educational Sciences of Ukraine, Kyiv, Ukraine

Abstract. The informational and analytical review of the main directions and results of the Institute of Vocational Education and Training of the National Academy of Educational Sciences of Ukraine activities in order to provide scientific and methodological support for professional education modernization, conduct experimental activities at different levels and implement innovations is enlightened in the report. It is emphasized that in the context of ensuring sustainable development of the national education system in the context of constant transformational changes, the Institute of Vocational Education and Training of NAES of Ukraine has been serving for fifteen years as a powerful scientific platform for the innovative development of vocational and professional pre-higher education institutions. The close collaboration with vocational, professional pre-higher education institutions, training and methodological (scientific and methodological) centers (cabinets) of vocational education and training; cooperation with different stakeholders; communication with the state and local authorities, ministries, and departments; development of international scientific relations are defined as the collaboration basis of the established scientific platform. Particular attention is paid to the dissemination of generalized and systematized results of basic and applied researches carried out at the Institute. The recommendations on modernizing the national vocational and professional pre-higher education systems are proposed.

Keywords: professional education; vocational education and training; professional pre-higher education; Institute of Vocational Education and Training of NAES of Ukraine; training and methodological (scientific and methodological) center (cabinet) of vocational education and training; scientific and methodological support; modernization of professional education.

Дата публікації: 6 квітня 2021 р. 